\title{
関係に対する展望が対人コミュニケーションに及ぼす影響 一関係継続の予期と関係継続の意思の観点から-1)
}

\author{
木 村 昌 紀 \\ 神戸学院大学人文学部
}

\author{
磯友輝子 \\ 東京未来大学こども心理学部
}

\author{
大 坊 郁 夫 \\ 大阪大学大学院人間科学研究科
}

\section{要 約}

本研究の目的は, 関係に対する展望が対人コミュニケーションに及ぼす影響を関係継続の予期と関係継続 の意思の観点から検討することである。先行研究では, 実験操作による外発的な関係継続の予期に注目して いた。そこで本研究では, 自発的に生起した関係継続の意思に注目して, これらの関係に対する展望が対人 コミュニケーションに及ぼす影響の共通点と相違点を調べた。未知関係 20 組 40 名と, 友人関係 25 組 50 名 の大学生が実験に参加した。結果は以下のとおりであった。先行研究と一致して, これからも関係が続いて いくと思うときは, コミュニケーションの動機づけが促進されて, 対人的志向性の個人差が消失した一方で, その場限りの一時的な関係と思うときは，社会的スキルの高い人ほど，積極的にコミュニケーションに取り 組んでいた。また, 先行研究では, 関係継続の予期があるときは相手を知るために視線量が増加したのに対 して, 本研究では, 関係継続の意思があるときは発話量が増加して, 対人コミュニケーションをポジティブ に認知していた点が異なっていた。そして, 関係継続の意思が対人コミュニケーションに及ぼす影響の程度 は，友人関係よりも未知関係において大きかった。

キーワード : 関係に対する展望, 対人コミュニケーション, 社会的スキル, 関係継続の予期, 関倸継続の意思

\section{問 題}

本研究の目的は, 未知関係と友人関係を対象にした一 連の会話実験によって, これからも関係が続いていくと いう「関係に対する展望」が対人コミュニケーションに 及ぼす影響を検討することである。その際に，外発的な 「関係継続の予期」と内発的な「関係継続の意思」の観点 から特に検討を行う。

\section{関係の継続性と対人コミュニケーション}

対人関係の展開に伴って, 対人コミュニケーションは 変化していく (e.g., Knapp \& Hall, 2010)。出会った頃は 何を話していいか分からず，互いに表情も硬くて，黙っ ていることが多かったのに，付き合っているうちに，表 情も柔らかくなり話が弾むようになった経験が誰しもあ
るだろう。対人関係の展開は, 今後も関係が続いていく かどうかという「関係の継続性」の点から捉えることが できる。日常生活の対人関倸は, 関係の継続性によって, その場限りで再び会うことのない「一時的関係」とこれ からも関係が続いていく「継続的関係」とに大きく分け ることができる。一般的に，一時的関係に比べて，継続 的関係ではコミュニケーションが促進される。たとえば, 一時的関係である, 実験のために招集された未知関係に 比べて, 継続的関係である友人関係では, 相手に多くの 視線を向け, 発言量が増寸傾向がある (e.g., 大坊, 1998)。 また, 間隔を空けて複数回の会話を行うことから関係の 継続性を実験的に操作した研究でも, 同様の知見が確認 されている。会話の回数を重ねるにつれて, 発言量（大 坊・杉山・吉村, 1975) や深い自己開示 (小川, 2008), 笑顔（山本・鈴木，2008）が増加する。このように, 実

1）本研究は，日本グループ・ダイナミックス学会第 55 回大会においてロング・スピーチとして報告された。 
際に関係の継続性が異なる対人関係を対象にした研究 や，実験的に関係の継続性を操作した研究から，関係の 継続性が対人コミュニケーションに影響を及ぼすことが 明らかになっている。

\section{関係に対する展望が対人コミュニケーションに及ぼす影響}

対人コミュニケーションに影響するのは現時点の関係 性だけではない。関係に対する，未来の展望をどのよう にもつのかが対人コミュニケーションに影響すると思わ れる。過去に経験した出来事を思い出すことができる動 物はたくさんいるけれども, 唯一人間だけがいまだ経験 したことのない未来について, 他の動物にはできないや り方で思い描くことができると, Gilbert（2006）が述べ ている。他のことと同じように我々は対人関係の展開に ついても未来を思い描く。同じ未知関係でも, その場限 りの一時的な関係と思うのか, 今後も関係が続いていく 関係に対する展望があるかによって, 対人コミュニケー ションに及ぼす影響が異なるのである。先行研究として, 実験的な操作によって関係に対する展望を外発的にもた せる「関係継続の予期」を扱ったものがある。Gergen and Wishnov（1965）によれば, 関係の継続が予期される場 合，相手に望ましい印象を与えようと動機づけられる。 また Baumeister（1982）は, 予期がある場合はより慎重 な印象管理を試みるという。さらに, これから関係が続 くという予期がある場合は, 不確実性を低減させるため, 相手のことをもつと知ろうとして情報収集に励むことが 報告されている (Berger, 1979）。これらの先行研究に共 通する点は，これからも関係が続いていくと思う「関係 継続の予期」がある場合, 相手の重要性が高まり, 対人 コミュニケーションの動機づけが促進されることである (Leary \& Miller, 2000)。

\section{状況の制約と対人的志向性 ${ }^{2)}$ の個人差}

「関係継続の予期」の有無により, 状況のもつ制約の程 度が異なると考えられる。誰しもに同じような心理的影 響を与える制約の強い状況に対して, 制約の弱い状況で は個人差を考慮する必要がある (Mischel, 1973)。つまり, 今後も関係が続いていく「関係継続の予期」がある状況 は，コミュニケーションの動機づけが促進されるという 強い制約があるのに対して, その場限りの一時的な関係 だと思う，「関係継続の予期」がない状況は相対的に制約
が弱いといえ, 対人的志向性の個人差が生じるのである。

対人的志向性の個人差として, 対人関係を円滑に営む 能力である「社会的スキル」が挙げられる。社会的スキ ルは, 目の前の他者からポジティブな反応を引き出し, ネガティブな反応を回避する能力として定義され(菊池, 2004), 訓練によって向上可能とされている。社会的スキ ルの測定には，自己報告が採用されることが多い。この 場合, 社会的スキルの実行段階よりも認知段階が強調さ れる（相川，2000）。すなわち，自己報告の場合，本人の 認識の範囲内での社会的スキルが測定されることにな る。この測定法による社会的スキルの高得点者は, 低得 点者に比べて, ストレスや不安, 疲労感などの心理的コ ストを抑えて，他者と関わることが可能である，と少な くとも仮定できる。

\section{先行研究の知見と課題 : 関係継続の予期と関係継続の意思}

木村・磯・大坊（2004）では，未知関係の実験参加者 を対象に, 実験的な操作によって, 関係継続の予期が対 人コミュニケーションに及ぼす影響を検討している。以 前には互いに面識のない, 未知関係の女性大学生をペア で実験室に招集し，半数のペアには，これから初対面の 相手と会話をしてもらうこと， $1 \sim 2$ 週間後に同じ相手 ともう 1 度会話してもらうことを教示した(「関係継続の 予期」あり条件)。もう半数のペアには, これから初対面 の相手と会話をしてもらうとだけ教示した(「関係継続の 予期」なし条件）。その際, 対人的志向性の個人差とし て，社会的スキルを自己報告によって測定している。そ の後, 会話を実施したところ, 関係継続の予期なし条件 に比べて，予期あり条件のほうが相手に多くの視線を向 けていた。加えて, 関係継続の予期あり条件では社会的 スキルの影響がみられなかった一方，予期なし条件では 社会的スキルの高い者ほど, 積極的に発言を行い,コミュ ニケーションをポジティブに認知していた。これらの結 果から，これからも関係が続いていくと思うときは相手 の重要性が高まり，コミュニケーションの動機づけが促 進して対人的志向性の個人差が消失寸ると思われる。そ れと対照的に, その場限りの一時的な関係と思うときは, 社会的スキルの高い者は他者と関わる心理的なコストが 少ないため，積極的に発言することで情報交換を行い， 対人コミュニケーションをポジティブに認知していた一 方で，社会的スキルの低い者は心理的なコストの割に見

2）「対人的志向性」という用語は, 他者に対する態度・関心・価値のみをあらわす場合もあれば, Rubin and Brown （1975）や斎藤・中村（1987）のように他者に対する行動といった反応性を含んだものをあらわす場合もあ る。前者を狭義の「対人的志向性」, 後者を広義の「対人的志向性」とすると, 本研究では広義の対人的志向 性を扱うことになる。 
木村・磯・大坊 : 関係に対する展望が対人コミュニケーションに及ぼす影響

返りが期待できないため, 消極的になって対人コミュニ ケーションをネガティブに認知していたことが示唆され ている。

木村ら（2004）では，外部操作による強制的な「関係 継続の予期」を扱っていた。ここでは，これからも関係 が続いていくと思う「関係に対する展望」の中でも, 実 験状況から，関係が続いていくものと思ってしまう，外 発的予期を扱っていたと言える。客観的な状況自体より, むしろ状況に対する主観的意味づけこそが心理的影響を 考える上で重要であるという指摘 (e.g., Krahé, 1992) や, 関係が続いていくと思うことには多様な側面があり，そ れらは区別されるべきという指摘（Arriaga \& Agnew, 2001）を考慮すれば，木村ら（2004）で得られた知見の 一般化可能性を探るため, 内発的に生じた「関係に対す る展望」の観点から「関係継続の意思」が対人コミュニ ケーションに及ぼす影響を検討する必要がある。

\section{「関係継続の意思」を調整する要因としての関係性}

内発的に生じた「関係継続の意思」を調整する要因と して対人関係の性質が考えられる。「未知関係」に比べ て，すでに関係を継続している「友人関係」は，互いが 重要な情緒的サポートの源泉であるため(浦, 1992), こ れからも関係を続けていくと思う, 関係継続の意思が非 常に高くなり, それゆえ誰しもコミュニケーションの動 機づけが高まって，対人的志向性の個人差が消失する可 能性がある。この関係継続の意思の程度は,「未知関係」 で関係継続の意思が高い場合よりもさらに上回るであろ う。しかし, 関係が長期にわたって継続することから, コミュニケーションへの動機づけが低下するという指摘も ある。Leary, Nezlek, Downs, Radford-Davenport, Martin, and McMullen（1994）によれば，長期的関係では，お互 いに関する情報が蓄積するため, 相手を知り, 自分を分 かってもらおうとする，コミュニケーションの動機づけ が低下しうる。ただし, 親密性が高ければ, その関係か らもたらされる自尊心の維持・高揚やアイデンティティ の確認といった効用から, コミュニケーションの動機づ
けは促進するという。ゆえに，友人関係を対象にして， 関係継続の意思が対人コミュニケーションに及ぼす影響 を検討する際は，「関係の継続期間」や「親密性」を考慮 する必要があろう。そこで, 本研究では未知関係と友人 関係という 2 種類の関係性を対象にして, 内発的な関係 継続の意思が対人コミュニケーションに及ぼす影響を検 討する。

\section{本研究の目的}

本目的の目的は，未知関係と友人関係の実験参加者を 対象にして，「関係継続の意思」3）が対人コミュニケー ションに及ぼす影響を検討することである。その際，先 行研究（木村ら，2004） と同様に, 対人的志向性の個人 差として社会的スキルに注目した。関係継続の予期を 扱った木村ら（2004）の知見は，関係継続の意思に注目 する本研究にも適用できると考えて, 未知関係と友人関 係それぞれについて，仮説 1 を設けた。

また，関係継続の意思を調整する要因として対人関係 の性質に注目し，未知関係と友人関係を比較することに よって検証を行う，仮説 2 を設けた。

仮説 1 内発的に生起した「関係継続の意思」がある場 合，コミュニケーションの動機づけが高まるため，社 会的スキルの影響がみられないであろう。一方，自発 的な「関係継続の意思」がない場合, 社会的スキルの 高い者ほど心理的コストが少ないため, 対人コミュニ ケーションに積極的に取り組むであろう。

仮説 2 すでに関係を継続している「友人関係」は，「未 知関係」に比べて, 内発的な「関係継続の意思」が高 く，それにともない，対人コミュニケーションに及ぼ す影響も大きいであろう。

そして, 関係継続の予期と関係継続の意思が, 対人コ ミュニケーションに及ぼす影響の相違点については，そ もそも相違点が存在するのか, もし相違点が存在すると すればどのような相違点なのか明確な予測を立てること ができなかったため，探索的に検討することとした。

3）本研究で注目する「関係継続の意思」は，親密な対人関係の研究領域では「コミットメント」と呼ばれるこ とがある。しかし，以下に述べる理由により，概念的多義性を避けるために，本稿では「関係継続の意思」 という言葉を用いた。まず，「関係継続の意思」が関係に対する展望に焦点化しているのに対して,「コミッ トメント」には付加的な心理的意味があると思われるためである。たとえば, Rusbult（1983）の「コミット メント」には，どのくらい関倸に関わっているのかという関与度が含まれており，Sternberg（1997）の「コ ミットメント」には, 愛するという決定や行為が含まれている。加えて, 説得的コミュニケーションの研究 領域において「コミットメント」は個人が行動に言質を与え, 行動に束縛されることを指す (e.g., Kiesler, 1971)。以上の理由から, 対人関係と対人コミュニケーションを研究対象とする本論文では, 概念的多義性を 避けるために「関係継続の意思」を採用した。 


\section{方法}

\section{実験参加者}

「未知関係」条件には, 実験以前には互いに面識のな い, 未知関係の女性大学生 20 組 40 名が参加した。実験 参加者の平均年齢は 18.88 歳, 標準偏差は 0.82 歳で, す べて初対面だった。また, 「友人関係」条件には, 友人関 係にある女性大学生 25 組 50 名が実験に参加した。平均 年齢は 18.60 歳, 標準偏差は 0.88 歳であった。

\section{手続き}

どちらの条件でも, 募集する際は「大学生のコミュニ ケーションに関する実験」を行うとだけ伝えた。「未知関 係」条件では, 実験以前に面識のない組み合わせにする ため, 心理学関連の異なる授業で実験参加者を募集し, 組み合わせてペアにした。実験室に招集する際は, 参加 者同士が顔を合わせないように招集場所と時間を変え て，それぞれの参加者を呼び出した。また「友人関係」 条件では, 心理学関連の授業において参加者を友人関係 のペアで募集した。どちらの条件でも，参加者が到着す ると,「これから行う実験は， 2 人で会話をしてもらい, 会話のパターンと心理的評価の関連を調べることが目的 である」という研究主旨を伝えた。その後で, 個別のブー スに案内して「未知関係」条件では社会的スキルに関す る質問項目に回答を求め, 「友人関係」条件では社会的ス キルや関係の継続期間, 親密性に関寸る質問項目に回答 を求めた。

次に, 会話ブースに移動して対面するよう着席して, 簡単な自己紹介を 5 分間自由に行った。その後, 一端個 別ブースに戻って, 自発的に生起した「関係継続の意思」 に関する質問項目に回答を求めた。

それから, 会話ブースに移動し，「互いをよく知り合え るように自由に会話してください」と教示して，本セッ ションとして互いに向かい合って 12 分間会話してもらっ た。会話の様子は, デジタルビデオカメラで撮影した。実 験者は別室に移動して, 会話の開始と終了を合図していた ため, 実験室には参加者だけがいる状況であった。会話終 了後, 参加者は個別ブースに戻って, 面識度と対人コミュ ニケーションの認知的側面に関する質問項目に回答した。

最後に, ディブリーフィングを行って, 実験を終了し た。ディブリーフィングの際に, インタビューを行った ところ, 実験中に参加者たちが特に違和感なく会話した ことを確認している。ここから, 実験室内という特殊な 状況下であるものの，実験参加者たちはある程度自由に 会話していたことがうかがえる。

\section{質問項目}

面識度の測定「未知関係」条件では, ペアになった参 加者が初対面であることを確認するため, 「友人関係」条 件では, ペアになった参加者に面識があることを確認す るため, 面識度に回答を求めた。「まったく知らなかっ た」「顔を見たことはあった」「あいさつしたことがあっ た」「世間話をしたことがあった」「たびたび話をする機 会があった」「頻繁に話をしている」「悩み事の相談をし たことがある」から当てはまるものを 1 つだけ選択して もらった。「未知関係」条件では実験参加者はすべて初対 面であり,「友人関係」条件では実験参加者はすべて面識 があった。

関係性の測定「友人関係」条件では関係性について詳 しく測定した。関係の継続期間について，どのくらい 2 人の関係が続いているかを月単位で回答するように求め た。また，親密性について，金政・大坊（2003）による， 愛情の三角理論尺度から「親密性」に関寸る項目（10 項 目， 7 件法）に回答を求めた。具体的な項目は，「○○さ んは必要な時には私を頼ることができる」「私と○○さん との関係は温かいものである」「○○さんとの関係は居心 地の良いものである」などであり,「○○さん」には会話 相手の友人を想定してもらい, 回答を求めた。

社会的スキルの測定 社会的スキルの質問項目とし て, 菊池（1988）の KiSS-18を用いた。KiSS-18は，「他 人と話していて, あまり会話が途切れないほうですか」 「他人にやってもらいたいことを,うまく指示することが できますか」など 18 項目から構成されており,「1=いつ もそうでない」から「5=いつもそうだ」の 5 件法で回答 を求めた。

関係継続の意思の測定 自発的に生起した「関係継続 の意思」を，「この人とずっと付き合っていきたい」「こ の人のことをもっと知りたい」「この人ともっと親しくな りたい」の 3 項目を用いて,「まったくそう思わない＝1」

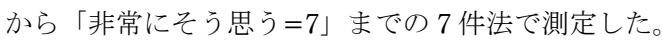

対人コミュニケーションの認知的側面の測定 木村・ 余語・大坊（2005）の 18 項目を用い, 各項目に対し, 「まったくそうでない」から「まったくそのとおりであ る」の 8 件法で回答を求めた。具体的な項目は, (1)会話 を上手く調整することができた, (2)会話に退屈していた, (3)協力的に会話が進んだ, (4)調和のとれた会話だった, (5)不満足な会話であった, (6)テンポの悪い会話だった, (7)冷たい感じの会話であった, 8)ぎこちない会話だった, (9)会話に夢中になった，10会話の焦点が定まっていな かった，11相互に興味をもって会話に取り組んだ，12)緊 張する会話だった，13好意的に会話ができた，14活発に 
木村・磯・大坊 : 関係に対する展望が対人コミュニケーションに及ぼす影響

表 1

対人コミュニケーションの行動指標の操作的定義

\begin{tabular}{|c|c|}
\hline 行動の種類 & 操作的定義 \\
\hline 視線 & 相手に対して視線を向けている状態。 \\
\hline 笑顔 & 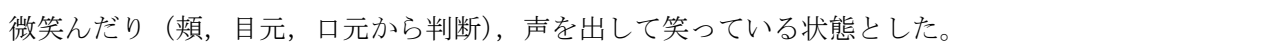 \\
\hline 発話 & $\begin{array}{l}\text { 音声を発している状態として定義した。「うんうん」や「はいはい」などの音声を伴う相づちは発話に } \\
\text { 含み，咳払い・鼻息は含まない。 }\end{array}$ \\
\hline 自己接触 & 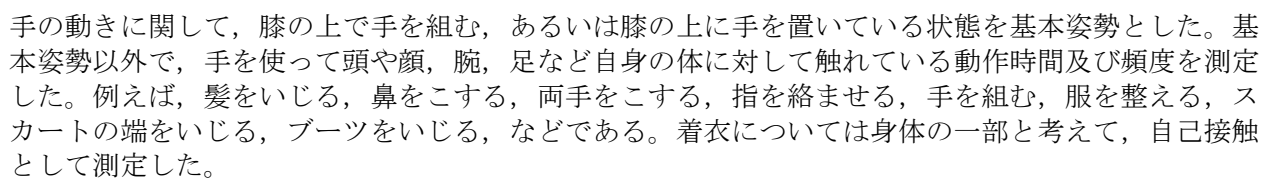 \\
\hline
\end{tabular}

会話した, 15)互いに肯定的に会話が進んでいた, 16)会話 は退屈なものだった，17会話は価值あるものだった，18) 間のびした会話だった，であった。逆転項目は，(2)(5)(6) (7)8(1012)(16)18)であった。この質問項目は 1 因子構造を有 し, 得点が高いほど対人コミュニケーションをポジティ ブに認知していることを示す $(\alpha=.94)$ 。

\section{対人コミュニケーションの行動的側面の測定}

対人コミュニケーションの行動的側面を測定するた め，荒川・鈴木（2004）のイベント・レコーダーを用い て, 撮影された本セッションの音声映像を見ながら, 視 線・笑顔・発話・自己接触の生起時間について, 訓練を 受けた 2 名のコーダー（実験者と社会心理学を専攻する 大学院生 1 名）が定量化した。イベント・レコーダーの 時間的分解能は 0.5 秒だった。各指標の操作的定義は表 1 に示す。定量化された指標の一致率を確認するため, それぞれの行動指標の生起時間についてコーダー 2 名に よるPearsonの積率相関係数を算出した。「未知関係」条 件の一致率はそれぞれ視線 $(r=.86, p<.01)$, 笑顔 $(r=.77$, $p<.05)$, 発話 $(r=.94, p<.01)$, 自己接触 $(r=.71, p<.01)$ であり,「友人関係」条件の一致率はそれぞれ視線 $(r=.45$, $p<.01)$, 笑顔 $(r=.33, p<.05)$, 発話 $(r=.89, p<.01)$, 自 己接触 $(r=.71, p<.01)$ であった。続く分析では, 寸心゙ ての指標についてコーダー 2 名のコーディング結果の平 均値を算出して用いた。

\section{結果}

\section{関係継続の意思と対人コミュニケーション}

まず, 未知関係の実験参加者を対象に,「関係継続の意 思」が対人コミュニケーションに及ぼす影響を検討した。 「関係継続の意思」に関する質問項目の内的整合性を確認 して $(\alpha=.94)$, 平均值を算出した $(M=4.62, S D=1.34)$ 。
外発的予期の影響に注目していた先行研究（木村ら, 2004）では，「関係継続の予期」あり条件と「予期」な し条件を設けて検討していた。先行研究との比較を容易 にするため, 本研究でも第一印象から内発的に生じた「関 係継続の意思」の中央值（4.67）を基準にして，「継続 意思」高群と「継続意思」低群に分割した。その際，対 人関係を円滑に営む能力である社会的スキルの高い者ほ ど，相手との関係性をこれからも続けていきたいと思う 可能性から,「関係継続の意思」の高低群間で社会的スキ ル得点に違いがあることが政念された。このことを確認 するために $t$ 検定を行ったところ,「関係継続の意思」高 群 $(M=3.21, S D=0.45)$ と「継続意思」低群 $(M=2.99$, $S D=0.50 ）$ には，社会的スキル得点に有意差がみられな かった $(t(38)=1.43, n . s$.$) 。表 2$ に，未知関係について「関 係継続の意思」高低群別で対人コミュニケーションの認 知的側面・行動的側面の平均值および標準偏差を示した。

次に, 友人関係の実験参加者を対象にして,「関係継続 の意思」について検討した。自発的に生起した「関係継 続の意思」に関する質問項目の内的整合性を確認し $(\alpha=.84)$ ，平均值を算出した $(M=6.48, S D=0.63)$ 。平 均值の高さと分散の小ささから, 友人関係にある実験参 加者は，概して，これからも関係が続くと強く思ってい ることが示された。「関係の継続期間」は平均 22.06 力 （標準偏差 35.53）であり, 範囲は 1力月～14 年 2 カ月で あった。そして, 親密性に関する質問項目の内的整合性を 確認して $(\alpha=.93)$, 平均值を算出した $(M=5.32, S D=$ 1.04)。この結果から, 実験参加者はペアになった友人 に対して,ある程度親密性を感じていることが示された。 これらの変数間の関連性を調べたところ, 関係の継続期 間は関係継続の意思 $(r=.15, n . s$.$) , 親密性 (r=.01, n . s$. ともに有意な関連がみられなかった一方, 親密性と関係 継続の意思の間には有意な正の相関関係がみられた 
表 2

「関係継続の意思」と対人コミュニケーションの認知的側面・行動的側面（カッコ内は標準偏差）

\begin{tabular}{llllllll}
\hline & & 認知的側面 & \multicolumn{1}{c}{ 視線 } & \multicolumn{1}{c}{ 笑顔 } & 発話 & 自己接触 \\
\hline \multirow{2}{*}{ 未知関係 } & 関係継続の意思 & 高 & $6.62(0.73)$ & $40.33(12.05)$ & $17.14(9.26)$ & $36.64(8.07)$ & $8.76(4.95)$ \\
& 関係継続の意思 & 低 & $6.01(1.29)$ & $44.77(9.60)$ & $13.90(6.28)$ & $29.76(8.10)$ & $8.00(4.00)$ \\
\hline 友人関係 & 関係継続の意思 & & $6.72(0.89)$ & $45.50(7.59)$ & $10.35(4.25)$ & $31.76(8.00)$ & $8.58(4.35)$ \\
\hline
\end{tabular}

註 : 行動的側面については1分あたりの生起時間 (単位 : 秒)。

$(r=.71, p<.01)$ 。こから, 親しみを感じる関係ほどそ の関係を続けたいと思うことが示された。友人関係にお ける対人コミュニケーションの認知的・行動的側面の平 均值と標準偏差を表 2 に示す。

\section{仮説 1 の検証}

本研究の仮説 1 を検証するため, 未知関係と友人関係 を対象にして，自発的に生起した「関係継続の意思」の 高低により，社会的スキルと対人コミュニケーションが どのように関連するのかを検討した。

はじめに，未知関係の実験参加者を対象にして検討を 行った。KiSS-18 について, 内的整合性を確認し $(\alpha=.79)$, 合計值を算出した $(M=55.62, S D=8.82)$ 。この結果は菊 池（1988）や木村ら（2004）とほぼ一致しており, 未知 関係のサンプルは特に偏りがなかったといえる。次に， 「関係継続の意思」高群で, 社会的スキルと対人コミュニ ケーションの行動的側面との Pearsonの積率相関係数を 算出したところ, 有意な関連性はみられなかったが $(r s=-.26 \sim .16, n . s$.$) , 認知的側面でのみ有意な正の相関$ 関係が得られた $(r=.63, p<.01)$ 。「関係継続の意思」低 群で, 同様に Pearsonの積率相関係数を算出したところ, 対人コミュニケーションの認知的側面 $(r=.64, p<.01)$ に 加えて, 発話 $(r=.58, p<.01)$ や笑顔 $(r=.58, p<.01)$ で 有意な正の相関関係がみられた。これらの結果から, 未 知関係において仮説 1 はほぼ支持された。

それから, 友人関係の実験参加者を対象にして検討し た。社会的スキルを得点化するために, KiSS-18の内的整 合性を確認して $(\alpha=.86)$, 合計值を算出した $(M=57.71$, $S D=9.54)$ 。この結果は菊池 (1988) や木村ら (2004), 未 知関係とほぼ一致しており, 友人関係のサンプルにも偏 りがなかったといえる。また, 友人関係においても社会 的スキルの高い者ほど, 相手との関係性がこれからも続 いていくと思う可能性が存在することから, 社会的スキ ルと関係継続の意思に正の相関関係がみられる懸念が あった。そこで, 社会的スキルと関係継続の意思の Pearsonの積率相関係数を算出したところ, $r=-.13$ (n.s.)
であり，有意な関連性はみられなかった。

友人関係において仮説 1 を検証するために，社会的ス キルと対人コミュニケーションの認知的側面・行動的側 面との関連性を検討したところ，認知的側面・行動的側 面ともに，社会的スキルと有意な関連性はみられなかっ た $(r s=-.06 \sim .24, n . s$.$) 。関係の継続期間や親密性を統制$ した偏相関係数を算出しても同様の結果であった。友人 関係にある参加者は概して自発的に生起した「関係継続 の意思」が非常に高く，これからも関係が続いていくと 強く思っていたため，本研究の仮説 1 は支持されたと考 えられる。

\section{仮説 2 の検証}

本研究の仮説 2 を検証するため, 自発的に生起した関 係継続の意思や，対人コミュニケーションについて未知 関係と友人関係で比較した。具体的には, 未知関係の「関 係継続の意思」低群と「継続意思」高群，全般的に「継 続意思」の高い友人関係の 3 群を比較した。

まず，自発的に生起した「関係継続の意思」を従属変 数にして 1 要因 3 水準の分散分析を行った結果, 有意な 主効果が得られた $(F(2,87)=110.98, p<.01)$ 。多重比較 からすべての群間に有意な差がみられた（未知関係の継 続意思低群 <未知関係の継続意思高群<友人関係群)。ま た，対人コミュニケーションの認知的側面でも，有意な 主効果があり $(F(2,87)=4.80, p<.01)$, 友人関係群や未 知関係の継続意思高群のほうが，未知関係の継続意思低 群に比べてポジティブに認知していた。行動的側面でも, 発話に主効果がみられた $(F(2,87)=3.53, p<.05)$ 。多重 比較の結果, 未知関係の継続意思高群のほうが, 未知関 係の継続意思低群に比べて，発話量が有意に多かった。 視線と自己接触では主効果がみられなかった。ただし, 笑顔で主効果がみられ $(F(2,87)=8.89, p<.01)$, 友人関 係群に比べて未知関係の継続意思高群において笑顔が有 意に生起していた。これらの結果から，仮説 2 は関係継 続の意思について支持された一方で，対人コミュニケー ションについては支持されなかった。 
木村・磯・大坊 : 関係に対する展望が対人コミュニケーションに及ぼす影響

\section{考 察}

外発的に生起した「関係継続の予期」を扱っていた先 行研究に対して, 本研究では未知関係と友人関係を対象 にした一連の会話実験から, 自発的に生起した「関係継 続の意思」が対人コミュニケーションに及ぼす影響を検 討した。関係に対する展望の中でも, 外発的な「関係継 続の予期」と内発的な「関係継続の意思」を比較するこ とで, 両概念の共通点と相違点を調べた。その際, 対人 的志向性の個人差として社会的スキルに注目した。

\section{「関係継続の予期」と「関係継続の意思」の共通点}

未知関係と友人関係を対象にした会話実験の結果か ら, 外発的な「関係継続の予期」と, 内発的な「関係継 続の意思」とで類似した傾向が示された。未知関係にお いて, 自発的に生起した「関係継続の意思」が高い場合 は, 対人コミュニケーションの行動的側面で社会的スキ ルの個人差が消失していた。これは, 自発的に生起した 「関係継続の意思」が高い場合, つまり, これから関係を 続けたいと強く思うときには，誰しもコミュニケーショ ンの動機づけが促進されるためだと考えられる。このこ とは,「関係継続の意思」低群に比べて「関係継続の意 思」高群のほうが，有意に発話量が高かったことからも 裏付けられる。ただし, 対人コミュニケーションの認知 的側面では社会的スキルの効果がみられた。それに対し て, 自発的に生起した「関係継続の意思」が低い場合, すなわち，関係を続けたいと思わないときは，社会的ス キルの高い者ほど，積極的に情報交換を行って，対人コ ミュニケーションをポジティブに認知していた。外発的 な「関係継続の予期」がある場合に比べて外発的な「予 期」がない場合のほうが，内発的な「関係継続の意思」 が高い場合に比べて内発的な「継続の意思」が低い場合 のほうが, 対人的志向性の個人差が生じやすく, 社会的 スキルが対人コミュニケーションに及ぼす影響が顕在化 するようである。関係が続いていくと思うことには多様 な側面があり，それらを区別するべきであり（Arriaga \& Agnew, 2001), 客観的な状況自体よりも, むしろ状況に 対する主観的意味づけこそが心理的影響を考える上で重 要だとしても（e.g., Krahé, 1992）, 「関係継続の意思」を 扱った本研究の知見は, 外発的な「関係継続の予期」を 扱った先行研究（木村ら，2004）と一貫性を有するとい えるだろう。

友人関係にある実験参加者は, 概して, これからも関 係を続けたいと強く思っていた。そのため, コミュニケー ションの動機づけが高まり，社会的スキルの個人差によ
る影響はみられなかったと思われる。このことは，未知 関係を対象に自発的に生起した「関係継続の意思」が対 人コミュニケーションに及ぼす影響を検討した結果にも 一致している。加えて, 関係の継続期間や親密性の影響 を統制しても, 結果は変わらなかったことから, 本知見 の頑健性が示唆される。

\section{「関係継続の予期」と「関係継続の意思」の相違点}

内発的な「関係継続の意思」を扱った未知関係の結果 で, 外発的な「関係継続の予期」を扱っていた先行研究 （木村ら，2004）と異なる点もあった。「関係継続の意思」 を扱った未知関係では，これからも関係を続けたいと強 く思うとき, 関係を続けたいとはそれほど思わないとき に比べて発話量が増加していた。それに対して, 木村ら （2004）の研究では，関係が続くと思うときには，その 場限りの一時的な関係と思うときに比べ, 視線量が増加 し，対人コミュニケーションをポジティブに認知してい た。これらの結果の整合性について考察する必要がある。 木村ら（2004）で, 外発的に関係継続の予期が与えられ た場合には，相手がどのような人物かを見極める必要が あり，情報収集を行うために視線量が増加していたのか もしれない。対照的に, 未知関係で内発的な関係継続の 意思が高い場合には，相手に関与することは意思決定済 みであるため，積極的に発言して情報交換を行い，結果 的にコミュニケーションをポジティブに認知していたと 思われる。これは, 自律性が活動への積極的参加とより 良い結果を導くとする知見（Deci \& Flaste, 1995）に符合 している。

\section{対人関係の性質と関係継続の意思}

ただし，友人関係において「関係継続の意思」が対人 コミュニケーションに及ぼす影響は，未知関係ほど強く はなかった。このことは, 未知関係と友人関係の比較分 析結果から示された。関係継続の意思の程度は, 友人関 係のほうが未知関係で関係が続くと強く思う人たちより も高かったものの, 対人コミュニケーションの認知的側 面・行動的側面では，未知関係で関係が続くと強く思う 人たちを上回ることはなかった。友人関係や未知関係で 関係を続けたいと強く思う人は，未知関係でそれほど関 係が続くと思わない人たちよりも，対人コミュニケー ションをポジティブに認知していた。また，未知関係で 関係を続けたいと思う人のほうが，関係を続けたいとあ まり思わない人よりも, 発話量が多かったものの, 友人 関係との間には有意な違いがみられなかった。ここから， 友人関係において, 自発的に生起した「関係継続の意思」 
が対人コミュニケーションに及ぼす影響が示唆されたも のの, 影響の程度は未知関係ほど強くはないようである。 このことの原因として，友人関係はコミュニケーション する機会が多いため, 関係継続の意思が一回のコミュニ ケーションには反映しにくい可能性や, 相手に関する情 報がこれまでに蓄積されているため, 発話量が少なくて もコミュニケーションが十分成立する可能性がある。た だ, 友人関係に比べて未知関係の「継続の意思」高群で 笑顔が多く生起していた結果は, 未知関係に比べて友人 関係で笑顔が生起するという先行研究の知見 (e.g., 山 本・鈴木, 2005）に合致せず, 本研究のデータのみから 解釈することが難しい。

\section{今後の展開}

本研究では検討しきれなかった課題がある。まず，今 後は実験計画段階で対人的志向性の要因配置が必要であ る。次に, 社会的ネットワークの中で関係に対する展望 を位置づけて考える点が挙げられる。日常生活において 対人関係は第三者や所属集団から影響を受けており，本 知見を一般化していくために，これを考慮しなければな らない。そして, 文化の問題がある。社会的流動性が文 化によって異なるため, 対人関係に対する未来の展望や, それが対人コミュニケーションに及ぼす影響も, 文化に よって異なることが考えられる。さらに, 本研究の実験 参加者は女性に限定されていたが, 実験参加者が男性の 場合も同じ結果が得られるかを確認寸る必要があるだろ う。これらの課題をクリアした上で, 現時点での関係の 進展段階に加えて, 関係に対寸る展望を考慮したコミュ ニケーション・モデルを構築することが, 今後の大きな 研究目標となる。

\section{おわりに}

対人関係は, 継続的な関係と一時的な関係の両輪であ る。Bowlby（1969/2000, 1973/2000）によれば，セキュア ベースとして位置づけられる, 親密な他者の存在が積極 的な探索的活動を促すという。また Granovetter（1973） は, 強い紐帯が日常生活の基本となり, 弱い紐帯が通常 は得難い有用な情報源になると説明している。そして， 山岸（1998）では，内集団の対人関係が社会的不確実性 を低減し, 外集団との関わりは新しい社会的活動の機会 を生み出すと主張されている。我々は継続的関係を基礎 にして，新しい関わりへと積極的に取り組むことができ る。ただし，現代社会では，国際交流の活発化や職場間 の流動化, インターネットの浸透で, 時間をかけた人と 人との関わりの機会が減る一方, 短い時間での関わりや
一時的な関わりの機会が増加している。日常生活におい て, 我々はこれまで以上に出会いと別れを繰り返してい るのである。これから関係が続いていくと思う場合，そ のコストを惜しまずに積極的に他者に働きかけて，情報 収集を試みる。しかし，一時的関係と思う場合でも，そ の出会いから何かを学び，その関わりの瞬間を楽しむこ とができれば，人生の豊かさが大きく増すだろう。現代 社会において, 対人コミュニケーションという現象を, 関係に対する未来の展望と対人的志向性の個人差の観点 から，あらためて見つめ直す価值があると思われる。

\section{謝辞}

本研究の実施や論文執筆過程で, 釘原直樹先生（大阪 大学), 谷口淳一先生 (帝塚山大学), 五十嵐祐先生 (北 海学園大学), 真島理恵先生 (熊本学園大学) に協力いた だきました。また, 対人コミュニケーションの行動的側 面を定量化する際, 清水裕士先生（日本学術振興会, 関 西学院大学: 現 広島大学) に協力していただきました。 そして, 審査者の先生方から有益なコメントをいただき ました。ここに謝意を表します。

\section{引用文献}

相川 充 (2000). 人づきあいの技術一社会的スキルの心 理学一 サイエンス社

荒川 歩・鈴木直人 (2004). しぐさと感情の関連の探索 的研究 感情心理学研究, 10, 56-64.

Arriaga, X. B., \& Agnew, C. R. (2001). Being committed: Affective, congnitive, and conative components of relationship commitment. Personality and Social Psychology Bulletin, 27, 1190-1203.

Baumeister, R. F. (1982). Self-esteem, self-presentation, and future interaction: A dilemma of reputation. Journal of Personality, 50, 29-45.

Berger, C. R. (1979). Beyond initial interaction: Uncertainty, understanding, and the development of interpersonal relationships. In H. Giles, \& R. St. Clair (Eds.), Language and Social Psychology. Oxford: Basil Blackwell.

Bowlby, J. (1969/2000). Attachment and loss, vol.1: Attachment. New York: Basic Books.

Bowlby, J. (1973/2000). Attachment and loss, vol.2: Separation. New York: Basic Books.

大坊郁夫 (1998). しぐさのコミュニケーション一人は親 しみをどう伝えあうか一 サイエンス社

大坊郁夫・杉山善朗・吉村知子 (1975) 。者間コミュニ 
ケーションにおける不安性の効果一とくに, 高・低 両極の不安水準の機能について一 実験社会心理学 研究, 15, 1-11.

Deci, E. L., \& Flaste, R. (1995). Why we do what we do.: The dynamics of personal autonomy. New York: G. P. Putnam's Sons.（桜井茂男（監訳）（1999）。人を伸ば 寸力一内発と自律の寸寸め一 新曜社)

Gergen, K. J., \& Wishnov, V. B. (1965). Other's selfevaluation and interaction anticipation as detreminants of self-presentation. Journal of Personality and Social Psychology, 2, 348-358.

Gilbert, D. (2006). Stumbling on happiness. New York: Knopf Publishing Group.（熊谷淳子（訳）（2007）。幸 せはいつもちょっと先にある一期待と妄想の心理 学一早川書房)

Granovetter, M. S. (1973). The strength of weak ties. American Journal of Sociology, 78, 1360-1380.

金政祐司・大坊郁夫 (2003). 愛情の三角理論における 3 つの要素と親密な異性関係 感情心理学研究, 10, $11-24$.

Kiesler, C. E. (1971). The psychology of commitment: Experiments linking to belief. New York: Academic Press.

菊池章夫（1988）。思いやりを科学する 川島書店

菊池章夫 (2004). KiSS-18 研究ノート 岩手県立大学社 会福祉学部紀要, 6, 41-51.

木村昌紀・磯友輝子・大坊郁夫 (2004). 関係継続の予期 が対人コミュニケーションに及ぼす影響 電子情報 通信学会技術報告, 104, 1-6.

木村昌紀・余語真夫・大坊郁夫 (2005). 感情エピソード の会話場面における表出性ハロー効果の検討 感情 心理学研究, 12, 12-23.

Knapp, M., \& Hall, J. A. (2010). Nonverbal communication in human interaction $7^{\text {th }} e d$. Belmont, CA: Wadsworth.

Krahé, B. (1992). Personality and Social Psychology. London: Sage Publication. (堀毛一也（監訳）（1996）. 社会的 状況とパーソナリティ 北大路書房)

Leary, M. R., \& Miller, R. S. (2000). Self-presentational perspectives on personal relationships. In S. W. Duck,
\& W. Ickes (Eds.), The social psychology of personal relationships. New York: Wiley \& Sons, pp. 129-155. (レアリー, M. R.・ミラー, R. S.・谷口淳一（訳） (2004) . パーソナルな関係における自己呈示的な パースペクティブ イックス, W.・ダック , S.・大 坊郁夫・和田 実（監訳）パーソナルな関係の社会 心理学 北大路書房 pp. 161-191.)

Leary, M.R., Nezlek, J. B., Downs, D. L., Radford-Davenport, J., Martin, J., \& McMullen, A. (1994). Self-presentation in everyday interactions. Journal of Personality and Social Psychology, 67, 664-673.

Mischel, W. (1973). Toward a cognitive social learning reconceptualization of personality. Psychological Review, 81, 252-283.

小川一美 (2008). 会話セッションの進展に伴う発話の変 化一Verbal Response Modesの観点から— 社会心理 学研究, 23, 269-280.

Rubin, J. Z., \& Brown, B. R. (1975). The social psychology of bargaining and negotiation. New York: Academic Press.

Rusbult, C. E. (1983). A longitudinal test of the investment model: The development (and deterioration) of satisfaction and commitment in heterosexual involvements. Journal of Personality and Social Psychology, 45, 101117.

斎藤和志・中村雅彦 (1987)，対人的志向性尺度作成の試 夕名古屋大学教育学部紀要一教育心理学科一, 34, 97-109.

Sternberg, R. J. (1997). Construct validation of a triangular love scale. European Journal of Social Psychology, 27, 313-335.

浦 光博 $(1992)$. 支えあう人と人一ソーシャル・サポー トの社会心理学— サイエンス社

山岸俊男 (1998). 信頼の構造一こころと社会の進化ゲー ム— 東京大学出版会

山本恭子・鈴木直人 (2005). 他者との関係性が表情表出 に及ぼす影響 心理学研究, 76, 375-381.

山本恭子・鈴木直人 (2008). 対人関係の形成過程におけ る表情表出 心理学研究, 78, 567-574. 


\title{
The effects of relational development prospect on interpersonal communication: Focusing on the expectation and will to continue a relationship
}

\author{
MASANORI KIMURA (Faculty of Humanities and Sciences, Kobe Gakuin University) \\ YUKIKo Iso (Department of Child Psychology, Tokyo Future University) \\ IKUO DAIBO (Graduate School of Human Sciences, Osaka University)
}

This study investigated how the prospect for development in a relationship affects interpersonal communication, taking into consideration the expectation and will to continue a relationship. Our prior study approached the matter experimentally by extrinsically manipulating the expectation for relational continuation, but this study featured self-initiated, on-going relationships, and examined consistencies and differences between expectancy of an ongoing relationship and will to continue a relationship. Twenty unacquainted dyads and 25 acquainted dyads participated in this experiment. Consistent with our prior study, when the relationship was considered continuous, they were motivated to communicate more, and the influence of individual differences in interpersonal orientation decreased. On the contrary, when the relationship was considered temporary, those with higher social skills conversed more with their partners. Compared to our prior study, there were some new findings. When they expected their relationship to extrinsically continue, they gazed at their partners more, while they talked more and perceived more satisfaction in a conversation with will to continue a relationship. Furthermore, will to continue a relationship influenced interpersonal communication more in unacquainted dyads than in acquainted.

Key Words: relational development prospect, interpersonal communication, social skills, expectancy of an ongoing relationship, will to continue a relationship 